\title{
Adsorption of Cyanide Contained in Aqueous Solution using Activated Carbon Obtained from Coffee Residue: Adsorption Efficiency; Equilibrium and Kinetic Models
}

Translation/republishing of the original version of the article which was published in the journal Scientia Agropecuaria, Issue 3 (2019), in Spanish

(http:/ / revistas.unitru.edu.pe/ index.php/ scientiaagrop/ article/ view/ 2550/ 2626).

\section{By Gonzalo Arangurí-LLerena \& Wilson Reyes-Lázaro}

Abstract- This research aimed to evaluate the adsorption process of cyanide ion $\left(\mathrm{CN}^{-}\right)$contained in synthetic aqueous solution, using activated carbon obtained from coffee residue, studying its efficiency and equilibrium and kinetic models. Activated carbon was characterized by Fourier Transform infrared analysis (FTIR), X-ray diffraction (DRX), and iodine number determination. A central composite design (CCD) with three factors adapted to three levels each and six central points was applied to study the effect of $\mathrm{pH}(\mathrm{A})$, contact time $(\mathrm{B})$ and adsorbent dosage $(\mathrm{C})$; According to the analysis of variance, the factors $A, B, C$, and the square $A A$ were significant in the adsorption efficiency of cyanide onto activated carbon, whose maximum value reached was $54.68 \%$ and $67.65 \%$ for the predictive level. According to the coefficient of determination $\left(R^{2}\right)$, Freundlich's isothermal model (0.954) and the three kinetic equations of pseudo-second order $(0.991,0.993,0.993)$ fit the experimental process. From the results obtained, the active carbon prepared from coffee residue can be used as a potential adsorbent of $\mathrm{CN}^{-}$, contained in aqueous solutions of low concentrations.

Keywords: adsorption; active carbon; cyanide; isotherm; coffee waste.

GJSFR-H Classification: FOR Code: 030703

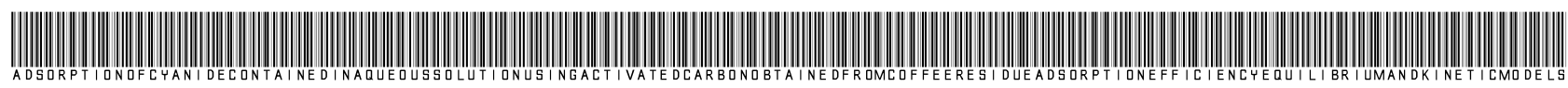

Strictly as per the compliance and regulations of:

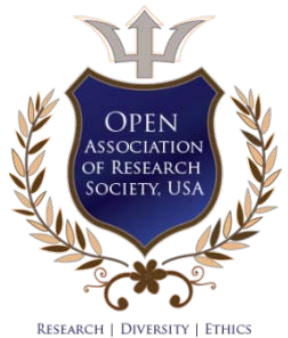

(c) 2020. Gonzalo Arangurí-LLerena \& Wilson Reyes-Lázaro. This is a research/review paper, distributed under the terms of the Creative Commons Attribution-Noncommercial 3.0 Unported License http://creativecommons.org/licenses/by-nc/3.0/), permitting all non commercial use, distribution, and reproduction in any medium, provided the original work is properly cited. 


\title{
Adsorption of Cyanide Contained in Aqueous Solution using Activated Carbon Obtained from Coffee Residue: Adsorption Efficiency; Equilibrium and Kinetic Models
}

\author{
Gonzalo Arangurí-LLerena ${ }^{\alpha} \&$ Wilson Reyes-Lázaro ${ }^{\circ}$
}

Abstract- This research aimed to evaluate the adsorption process of cyanide ion $(C N)$ contained in synthetic aqueous solution, using activated carbon obtained from coffee residue, studying its efficiency and equilibrium and kinetic models. Activated carbon was characterized by Fourier Transform infrared analysis (FTIR), X-ray diffraction (DRX), and iodine number determination. A central composite design (CCD) with three factors adapted to three levels each and six central points was applied to study the effect of $\mathrm{pH}(\mathrm{A})$, contact time (B) and adsorbent dosage (C); According to the analysis of variance, the factors $A, B, C$, and the square $A A$ were significant in the adsorption efficiency of cyanide onto activated carbon, whose maximum value reached was $54.68 \%$ and $67.65 \%$ for the predictive level. According to the coefficient of determination $\left(R^{2}\right)$, Freundlich's isothermal model (0.954) and the three kinetic equations of pseudo-second order $(0.991,0.993,0.993)$ fit the experimental process. From the results obtained, the active carbon prepared from coffee residue can be used as a potential adsorbent of $C N$, contained in aqueous solutions of low concentrations.

Keywords: adsorption; active carbon; cyanide; isotherm; coffee waste.

\section{InTRODUCTION}

T he $\mathrm{CN}^{-}$is one of the toxic chemicals found in sewage discharges from electroplating, metal finishing, steel hardening, mining (Processing of metals such as gold and silver), manufacturing of auto parts, photography, pharmaceuticals and coal processing units (Dwivedi et al., 2014), food and chemical synthesis (nylon, fibers, resins, fertilizers, pesticides, and herbicides) (Halet et al., 2015). It is estimated that the release of cyanide from industries is more than 14 million kg/year in the world (Gupta et al., 2012) and can exist in three forms: total cyanide (CNT), WAD cyanide (Weak acid dissociable) and free cyanide (CNL). The CNT includes strong metal-cyanide complexes, such as iron $\left(\left[\mathrm{Fe}(\mathrm{CN})_{6}\right]^{3-},\left[\mathrm{Fe}(\mathrm{CN})_{6}\right]^{4-}\right)$, gold $\left(\left[\mathrm{Au}(\mathrm{CN})_{2}\right]^{]}\right.$, cobalt $\left(\left[\mathrm{Co}(\mathrm{CN})_{6}\right]^{4}\right)$, and Cyanide WAD (CN WAD); which includes both: CNL and metal complexes of weak and moderately strong cyanide; such as cadmium $\left(\left[\mathrm{Cd}(\mathrm{CN})_{4}\right]^{2-}\right)$, zinc $\left(\left[\mathrm{Zn}(\mathrm{CN})_{4}\right]^{3-}\right.$, copper

Author a o: National University of Trujillo, Perú.

e-mail: garanguri@hotmail.com cyanides $\left(\left[\mathrm{Cu}(\mathrm{CN})_{2}\right]^{-}, \quad\left[\mathrm{Cu}(\mathrm{CN})_{3}\right]^{2-}, \quad\left[\mathrm{Cu}(\mathrm{CN})_{4}\right]^{3-}\right)$, nickel $\left(\left[\mathrm{Ni}(\mathrm{CN})_{4}\right]^{2-}\right)$ and silver $\left(\left[\mathrm{Ag}(\mathrm{CN})_{2}\right]\right)$; the $\mathrm{CNL}$ includes $\mathrm{CN}^{-}$and hydrogen cyanide (HCN) (Aranguri and ReyesLópez, 2018).

Cyanide when emitted in concentrations that exceed environmental regulations, constitutes a dangerous compound for humans, aquatic organisms and the environment in general, because it exerts an inhibitory action on certain metabolic enzymes; the main compound affected is the enzyme cytochrome $c$ oxidase; its inhibition causes the blocking of the electron transport chain at the mitochondrial level, avoiding the absorption of oxygen (Luque-Almagro et al., 2016). According to Azamat and Khataee (2017); Between 0.5 and $3.5 \mathrm{mg}$ of cyanide per kilogram of body mass in people can cause death.

The United States Environmental Protection Agency (USEPA) has proposed a regulation for drinking water regarding the CNT in $0.2 \mathrm{mg} / \mathrm{L}$ and in terms of $\mathrm{CNL}$ for protection of aquatic life in freshwater, it is set at 0.022 and $0.0052 \mathrm{mg} / \mathrm{L}$ (Botz et al., 2016). Peruvian regulations for water quality standards (DS N ${ }^{\circ} 002$ 2008 -MINAM), established the CN WAD at $0.1 \mathrm{mg} / \mathrm{L}$ (category 3: irrigation of vegetables and animal drinks) and for CNL at $0.022 \mathrm{mg} / \mathrm{L}$ (category 4: conservation of the aquatic environment).

Liquid emissions containing cyanide over the permissible limits are processed by conventional chemical methods such as alkaline chlorination, the INCO process ( $\mathrm{SO}_{2} /$ air) (International Nickel Company 's), hydrogen peroxide, the Caro's acid method $\left(\mathrm{H}_{2} \mathrm{SO}_{4} / \mathrm{H}_{2} \mathrm{O}_{2}\right)$, ozonation, among others (Aranguri and Reyes-López, 2018; Botz et al., 2016); however, for Dwivedi et al. (2014) chemical processes to degrade cyanide are not appropriate for environmental and economic perspectives; due to its high demand for chemical products and the formation of secondary pollutants, they need additional treatment before disposal and argues that adsorption is a simple and attractive method for the elimination of toxic effluent compounds due to their high efficiency, handling, and economic feasibility. 
According to bibliographic references, there are several reports of adsorbents; with and without treatment to adsorb $\mathrm{CN}^{-}$; namely: olive stone and coffee ground (Halet et al., 2015), shea butter seed husk (Tsunatu et al., 2015), coconut shell (Singh and Balomajumder, 2016), rice husk (Naeem et al., 2011), almond shells and leaves of teak (Dwivedi et al., 2016), active carbon (D 45/2 - Carbo Tech) (Stavropoulos et al., 2015) and in the present study, active carbon is used, prepared from the coffee residue, and a method little studied in the carbonization and activation of the precursor is explored; Nitrogen gas was not used to generate an inert atmosphere.

According to the International Coffee Organization (ICO), in 2018, the world coffee production was 168.093 million bags of $60 \mathrm{~kg}$. Its processing generates significant amounts of agricultural waste, ranging from $30 \%$ to $50 \%$ of the total coffee weight produced, depending on the type of processing (Oliveira and Franca, 2015). According to Mussatto et al. (2011), approximately 50\% of the world's coffee production is used to prepare soluble, and the ground coffee residues are in the order of 6 million tons per year, worldwide. The intention is to give added value to these wastes.

Thus, the purpose of the present work was to evaluate the adsorption process of cyanide, contained in aqueous solution, on activated carbon, obtained from coffee residue, studying its efficiency as well as the equilibrium and kinetic models.

\section{il. Materials and Methods}

\section{a) Preparation of activated carbon from coffee residue (CARC)}

Cofee residue (after roasting, grinding and extracting its flavorings), from the Coffea arabica variety, produced in the province of Chanchamayo (Perú), was collected from the "Valentino" cafeteria (Trujillo Central Market); washed with spout water to remove dust, impurities, and soluble substances; then it was rinsed with boiled distilled water until the black dye disappears and dried at $110^{\circ} \mathrm{C}$ for eight horas in a Universal Oven UF55- Memmert. Subsequently, carbonization and chemical activation is experienced at 500 and $450{ }^{\circ} \mathrm{C}$, respectively; in refractory clay crucible, provided with a lid (Guang-zhen et al., 2016); contained in a Barnstead Thermolyne 6000 electric muffle, for one hour for each stage. Nitrogen gas was not used to generate inert conditions; each crucible was supplied from its respective lid to avoid oxidizing atmosphere.

Before chemical activation; chemical impregnation was applied to carbon, with a solution of phosphoric acid $\left(\mathrm{H}_{3} \mathrm{PO}_{4}\right)$ (Halet et al., 2015; Shamsuddin et al., 2016) at 40\%; $3 \mathrm{~mL}$ of phosphoric acid is added for each gram of carbon (3 v/p) (Reffas et al., 2010) were stirred for 15 hours at $80^{\circ} \mathrm{C}$.
The yield and burn off in the carbonized process were measured according to (Reffas et al., 2010). The carbonization yield or degree of conversion to coal (Equation 1), is the percentage of the product obtained after carbonization concerning the dry weight of the precursor used and the burn-off or lost by combustion (Equation 2), is the percentage of precursor eliminated during the carbonization process ((Fombuena and Valentín, 2010).

The CARC was reduced and classified to a particle size between +74 and -500 microns, washed with distilled water to a neutral $\mathrm{pH}$, and dried at $150{ }^{\circ} \mathrm{C}$ for six hours.

$$
\begin{aligned}
& \text { Yield }(\%)=m_{2} \cdot 100 / m_{1} \\
& \text { Burn off }(\%)=\left(m_{1}-m_{2}\right) \cdot 100 / m_{1}
\end{aligned}
$$

Where: $m_{1}=$ initial precursor mass and $m_{2}=$ mass of carbon obtained.

\section{b) Characterization of the adsorbent}

The functional groups present on the surfaces of the coffee residue were determined; to its respective CARC and CARC after adsorbing $\mathrm{CN}^{\prime}$, applying a solid phase FTIR analysis, using a Thermo Nicolet IS50 FT-IR ATR spectrometer. To identify the amorphous nature and the metal oxides present in the CARC; A DRX analysis was performed using the Rigaku brand Diffractometer, model Miniflex 600. Likewise, its iodine number was determined, according to NMX-F-296-SCFI, 2011, and ASTM-D4607, 2006. For the three analyzes, the samples were reduced to a size of -75 microns.

\section{c) Optimization of the adsorption process}

The CCD was applied; their independent variables, and their respective levels, which determined the adsorption percentage $(Y)$ responses, are shown in Table 2. The adsorption tests of the $\mathrm{CN}^{-}$(mg/L), were performed randomly; Their results were evaluated using the Minitab 18 statistical software, with an " $\alpha$ " level of $5 \%$ and adsorption efficiency was calculated according to equation 3.

$$
\% \text { Adsorption }=\left(C_{i}-C_{t}\right) \cdot 100 / C_{i}
$$

Where $C_{i}$ and $C_{f}$, represent the initial and final concentration of $C N^{-}(\mathrm{mg} / \mathrm{L})$, for each test, respectively.

\section{d) Study of equilibrium and kinetic models}

To study the interaction of $\mathrm{CN}^{-}$molecules and the surfaces of the CARC particles, as well as identify a model equation to predict the equilibrium adsorption of the $\mathrm{CN}^{-}$by the CARC, the experimental equilibrium data were tested, with the isothermal models of Freundlich, Langmuir, and Temkin.

The separation factor or equilibrium parameter " $R_{L}$ " (constant without dimensions) is used to express the essential characteristics of the Langmuir isotherm (Equation 4). 


$$
R_{L}=1 /\left(1+b C_{0}\right)
$$

Where: $b$ is the Langmuir constant and $C_{0}$ is the initial concentration of $\mathrm{CN}^{-}$(mg/L). $R_{L}$ indicates the conditions of the isotherm. If, $R_{L}>1$ (unfavorable), $R_{L}=1$ (linear adsorption), $R_{L}=0$ (irreversible) and if $0<R_{L}<1$ (favorable) (Eletta et al., 2016; Gupta et al., 2013).

The mass transfer efficiency of the $\mathrm{CN}^{-}$to CARC was evaluated, applying the first and second-order pseudo models, and to determine whether intraparticle diffusion was the limiting stage for cyanide adsorption on CARC, the experimental data were analyzed by the Weber-Morris model.

For the equilibrium and kinetic study, the concentrations of $\mathrm{CN}^{-}$solutions were measured and the adsorption capacity in the equilibrium (qe, $\mathrm{mg} / \mathrm{g}$ ), was calculated; as well as the adsorption capacity of $\mathrm{CN}^{-}$at time $\mathrm{t}(\mathrm{qt}, \mathrm{mg} / \mathrm{g}$ ) for predetermined time intervals; according to equation 5 and equation 6 .

$$
\begin{aligned}
& \mathrm{qe}=\left(C_{0}-C_{e}\right) \cdot V / W \\
& \mathrm{q}=\left(C_{0}-C_{t}\right) . V / W
\end{aligned}
$$

Where $C_{0}(\mathrm{mg} / \mathrm{L})$ is the initial concentration of $\mathrm{CN}^{-} ; C_{e}$ $(\mathrm{mg} / \mathrm{L})$ is the concentration of $\mathrm{CN}^{-}$in the equilibrium; $C_{t}$ ( $\mathrm{mg} / \mathrm{L})$ is the $\mathrm{CN}^{-}$concentration of the cyanide solution at time $t(\mathrm{~min}) ; V(\mathrm{~L})$ the volume of the cyanide solution and $W(\mathrm{~g})$ the amount of activated carbon (Halet et al., 2015).

Table 1 shows the linear forms for the equilibrium and kinetic equations adapted from (Dwivedi et al., 2014) and from (Tsunatu et al., 2015).

\begin{tabular}{|c|c|c|}
\hline Models & Linear equation & Parameters \\
\hline \multicolumn{3}{|c|}{ Equilibrium models } \\
\hline $\begin{array}{l}\text { Freundlich } \\
\text { model }\end{array}$ & $\log q_{e}=\log K_{f}+1 / n \log C_{e}$ & $\mathrm{~K}_{\mathrm{f}}(\mathrm{mg} / \mathrm{g}) /(\mathrm{mg} / \mathrm{L}), 1 / \mathrm{n}$ and $\mathrm{n}$, are constants \\
\hline $\begin{array}{l}\text { Langmuir } \\
\text { model }\end{array}$ & $\mathrm{C}_{\mathrm{e}} / \mathrm{q}_{\mathrm{e}}=1 / \mathrm{Q}_{\max } \mathrm{b}+\mathrm{C}_{\mathrm{e}} / \mathrm{Q}_{\max }$ & $\begin{array}{l}\mathrm{Q}_{\max }(\mathrm{mg} / \mathrm{g}) \text { is the maximum adsorption capacity in the monolayer and b }(\mathrm{L} / \mathrm{mg}) \\
\text { is the constant related to the capacity and energy of adsorption, representing } \\
\text { the affinity between adsorbate and adsorbent. }\end{array}$ \\
\hline $\begin{array}{l}\text { Temkin } \\
\text { model } \\
\text { Kinetic models }\end{array}$ & $\mathrm{q}_{\mathrm{e}}=\mathrm{B} \ln \mathrm{A}+\mathrm{B} \ln \mathrm{C}_{\mathrm{e}}$ & $A$ and $B$ are the constants of Temkin \\
\hline $\begin{array}{l}\text { Pseudo first } \\
\text { order }\end{array}$ & $\log \left(q_{e}-q_{t}\right)=\log \left(q_{e}\right)-K_{1} t / 2,303$ & $\begin{array}{l}\mathrm{q}_{\mathrm{e}} \text { y } \mathrm{q}_{\mathrm{t}} \text { are the adsorption capacities }(\mathrm{mg} / \mathrm{g}) \text { of adsorbent, at equilibrium and } \\
3 \text { at a time "t," } \\
\mathrm{K}_{1} \text { is the pseudo first order adsorption rate constant }\left(\mathrm{s}^{-1}\right)\end{array}$ \\
\hline $\begin{array}{l}\text { Pseudo } \\
\text { second order }\end{array}$ & $t / q_{t}=1 / K_{2} q_{e}^{2}+t / q_{e}$ & $\mathrm{~K}_{2}$ is the pseudo second order adsorption rate constant ( $\mathrm{g} / \mathrm{mg} \mathrm{s}$ ) \\
\hline $\begin{array}{l}\text { Intra particle } \\
\text { diffusion }\end{array}$ & $\begin{array}{l}\mathrm{q}_{\mathrm{t}}=\mathrm{K}_{\mathrm{di}} \mathrm{t}^{1 / 2}+C \\
\text { (Weber-Morris (1963) }\end{array}$ & $\begin{array}{l}\mathrm{q}_{\mathrm{t}} \text { is sorption concentration at time "t". } \\
\mathrm{K}_{\mathrm{di}} \text { is the rate constant of intra } \\
\text { particle transport }\left(\mathrm{mg} / \mathrm{g} / \mathrm{time}^{1 / 2}\right) \text {. } \\
\mathrm{C}(\mathrm{mg} / \mathrm{g}) \text { it is a constant related to the thickness of the adsorbent boundary } \\
\text { layer }\end{array}$ \\
\hline
\end{tabular}

Table 1: Equilibrium and kinetic models used to explain adsorption processes
The tests for the isothermal and kinetic model will be carried out at ambient conditions $\left(30^{\circ} \mathrm{C}\right)$, using $50 \mathrm{ml}$ of $\mathrm{pH} 8$ synthetic solution with $1.5 \mathrm{~g}$ of adsorbent contained in $250 \mathrm{ml}$ flasks. The known concentrations for each test were diluted from a cyanide stock solution of $1000 \mathrm{mg} / \mathrm{L}$ of $\mathrm{CN}^{-}$and filtered after each test for analysis. An IKA WORKS KS orbital shaker is used for all agitation tests.

\section{e) Analytical measurements and of $\mathrm{pH}$}

Depending on the concentration of the solution, the $\mathrm{CN}^{-}$was determined, either by the cyanide ionselective electrode method or by titration; For the latter, Vogel's "method A" (Vogel, 1989) and Standard Methods 4500-CN-D (Greenberg et al., 1992) are considered with the adaptation of a concentration of silver nitrate $\left(\mathrm{AgNO}_{3}\right)$ of $2 \mathrm{~g} / \mathrm{L}(0.01 \mathrm{M})$ and as an indicator rhodamine (p-Dimethylamino benzalrhodamine) at 0.1 $\mathrm{g} / 100 \mathrm{~mL}$ of acetone. For the cyanide selective electrode method, a Thermo Scientific, Orion Versa Star Pro multiparameter, and a cyanide specific ion electrode, Thermo Scientific model, Orion 9606 BNWP are used. Potentiometric readings performed on a magnetic stirrer IKA WORKS, model C-MAG-HS7. The $\mathrm{pH}$ of all solutions was regulated by the addition of $\mathrm{HCl}$ or $\mathrm{NaOH}$ solutions (10 and $1 \mathrm{~N}$ for both) and was measured using a Thermo Scientific Orion electrode.

\section{ili. Results and Discussion}

\section{a) Preparation of CARC}

The yield and burn off, for carbonization (14.73\% and $85.27 \%$ ) and chemical activation $(72.86 \%$ and $27.14 \%$ ) of the coffee residue at 500 and $450{ }^{\circ} \mathrm{C}$ respectively were evaluated. Molina-Sabio and Rodríguez-Reinoso (2004) report that in the 
carbonization of lignocellulosic materials, the degradation of the precursor takes place between 200 and $350{ }^{\circ} \mathrm{C}$; for the present experiment studied, it occurred at an average temperature of $310^{\circ} \mathrm{C}$.

The carbonization yield (14.73\%); It is relatively superior to what was experienced by Reffas et al. (2010), who gives a value of $9.7 \%$ for simple carbonizations of the same material; This could be by the difference in the temperature of carbonization.

The yield obtained in the chemical activation stage is high (72.86\%); compared to the $50 \%$ yield found by Al Bahri et al. (2012) in the activation of seeds of grapes impregnated with $\mathrm{H}_{3} \mathrm{PO}_{4}(3 \mathrm{p} / \mathrm{v})$, in a singlephase and at 38 and $32 \%$ of Reffas et al. (2010) for chemical activation with single-step $\mathrm{H}_{3} \mathrm{PO}_{4}$ at $450{ }^{\circ} \mathrm{C}$, for ground coffee residues at different impregnation rates; This notable difference is because in the first phase of carbonization of the coffee residue, were expelled the most volatile material.

\section{b) Characterization of the adsorbent}

According to the FTIR analyzes of the precursor (Fig. 1a) it reveals that it has a broad adsorption band due to the formation of hydrogen bridges, with a peak around $3335 \mathrm{~cm}^{-1}$ and is related stretching vibration of the hydroxyl groups $\mathrm{OH}$, overlapping with $\mathrm{N}-\mathrm{H}$ junctions: alcohols-phenols, carboxyl and amino (Reffas et al., 2010), which is corroborated by the formation of signals at 1154 and $1032 \mathrm{~cm}^{-1}$ for phenols and alcohols, as well as the two acute bands at 2922 and $2853 \mathrm{~cm}^{-1}$ show the presence of the stretching vibrations $\mathrm{C}-\mathrm{H}$ (alkanes) (Ma and Ouyang, 2013). The peaks at 1743 and $1647 \mathrm{~cm}^{-1}$ are assigned to the stretching vibrations $\mathrm{C}=\mathrm{O}$ in the carboxylic acids, anhydrides, and lactones (Imessaoudene et al., 2016), and the acetyl group in the hemicellulose (Shamsuddin et al., 2016). The bands at 1455 and $1377-1240 \mathrm{~cm}^{-1}$ ascribed to the symmetrical and asymmetric bending of the $\mathrm{CH}_{3}$ group; also the $1240 \mathrm{~cm}^{-1}$ band is associated with the $\mathrm{C}-\mathrm{O}$ stretching of the aryl group in lignin (Shamsuddin et al., 2016). The signals between 666 and $871 \mathrm{~cm}^{-1}$ correspond to out of plane bending vibrations (Rattanapan et al., 2017) and the $\mathrm{N}-\mathrm{H}$ and $\mathrm{C}-\mathrm{H}$ aromatic groups (Reffas et al., 2010). Similar bands have been reported by Ballesteros et al. (2014) and Liu et al. (2015), who agree in their FTIR analysis, that the coffee bean has adsorption bands of lignocellulosic materials.

Fig. 1b shows the FTIR spectrum of CARC; it is appreciated that the precursor has undergone significant changes in its structure that suggests the complete carbonization of the precursor when subjected to the activation process. Volatile and organic compounds have decomposed or removed, resulting in an efficient modification of the surface of the carbon (Ma and Ouyang, 2013; Rattanapan et al., 2017). The band of the precursor between 3600 and $3050 \mathrm{~cm}^{-1}$, as well as the peaks at 2922, 2853, 1743, and $1032 \mathrm{~cm}^{-1}$, have virtually disappeared. Only a small peak of weak intensity remained around 2980 and $2900 \mathrm{~cm}^{-1}$ products of the $\mathrm{C}-\mathrm{H}$ aliphatic stretching in an aromatic methoxy group (Reffas et al., 2010; Xu et al., 2014) and the peaks observed around 1560 and $1150-1060 \mathrm{~cm}^{-1}$ are due to stretching vibrations type $C=C$ and $C-C$ respectively. The peak band to $1560 \mathrm{~cm}^{-1}$ is overlap with the bending vibration of the $\mathrm{N}-\mathrm{H}$ group (amines and amides); similarly the peaks at $1150-1060 \mathrm{~cm}^{-1}$ with the stretching vibrations $\mathrm{C}-\mathrm{O}$ of ethers, esters (Rattanapan et al., 2017) with shoulder at $1190 \mathrm{~cm}^{-1}$; they are characteristic signals of phosphocarbonaceous compounds present in carbons activated with phosphoric acid (Reffas et al., 2010). The band at $870 \mathrm{~cm}^{-1}$ is related to out of plane bending vibrations $\mathrm{C}=\mathrm{C}-\mathrm{H}$ (Rattanapan et al., 2017).

The spectrum of Fig. 1c has not undergone significant changes in the position of its peaks concerning Fig. 1b, however it has suffered a slight displacement at lower values of the transmittance percentage. It may be due to the adsorption of $\mathrm{CN}^{-}$onto active carbon. 


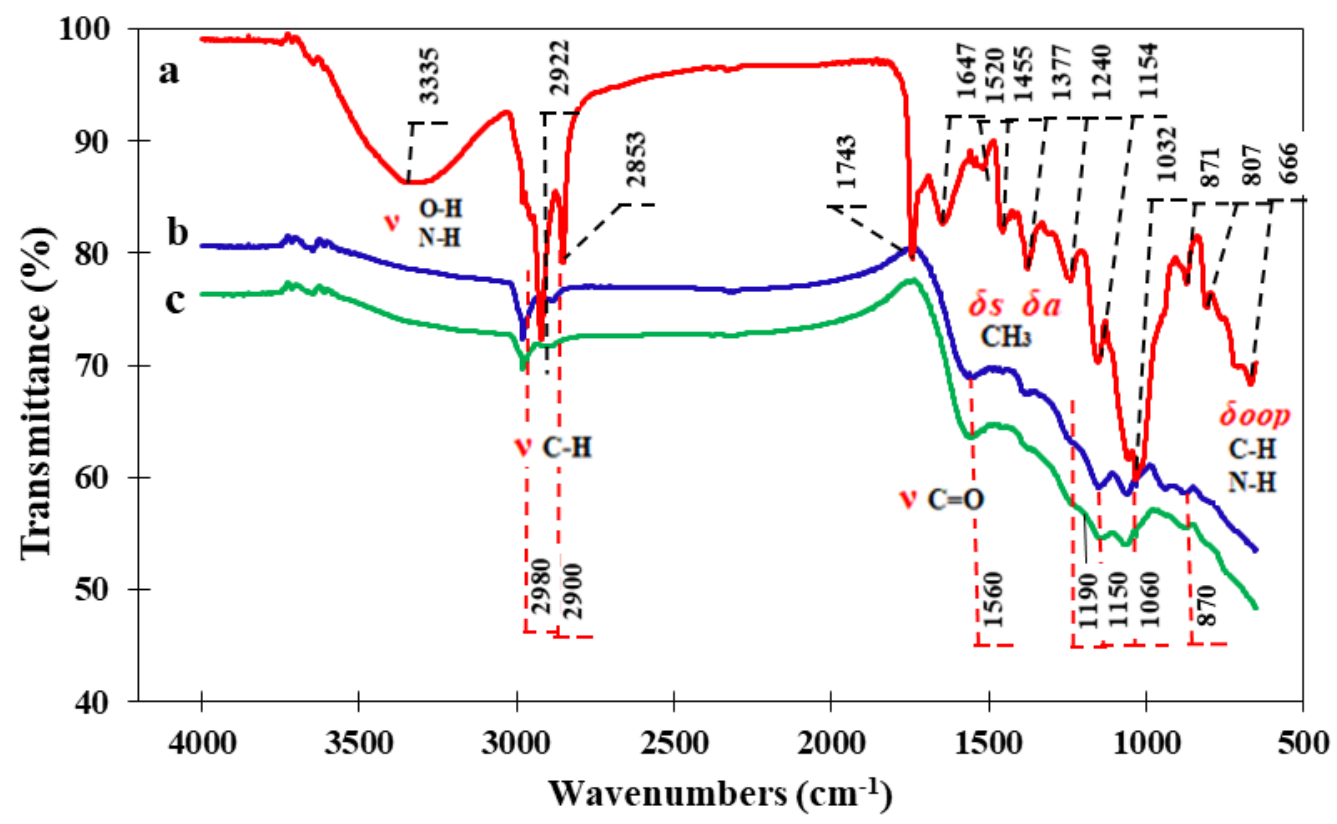

Fig. 1: Comparison of FTIR spectra. a) Coffee residue; b) CARC; c) CARC after adsorption test. The numbers indicated on the bands in the figure correspond to wavenumber $\left(\mathrm{cm}^{-1}\right)$. v: stretching vibrations; $\delta a$ : asymmetric bending vibrations, $\delta s$ : symmetrical bending vibrations; $\delta 00 p$ : out-of-plane bending vibrations.

According to the DRX (Fig. 2), two strong and wide diffraction peaks are observed at $23.58{ }^{\circ} \mathrm{C}$ and $43.6^{\circ} \mathrm{C}$ on the 2-theta scale, which corresponds to the planes (002) and (101) of the graphite carbon (Rawal et al., 2018), which are dominant characteristics of amorphous coals (Awasthi et al., 2018; Herrera et al., 2018;). According to Gupta et al. (2013), X-ray diffraction patterns in the broad peak of $15^{\circ}$ to $35^{\circ}$ indicate the presence of amorphous silica and alumina wairakite $\left(\mathrm{CaAl}{ }_{2}\left(\mathrm{SiO}_{3}\right)_{4} \cdot 2 \mathrm{H}_{2} \mathrm{O}\right)$, mordenite $\left.\left(\mathrm{Ca}, \mathrm{Na}_{2}, \mathrm{~K}_{2}\right) \mathrm{Al}_{2} \mathrm{Si}_{10} \mathrm{O}_{24} \cdot 7 \mathrm{H}_{2} \mathrm{O}\right)$, ferro-axinite $\left(\mathrm{Ca}_{2} \mathrm{Al}_{2} \mathrm{BSi}_{4} \mathrm{O}_{15} \mathrm{OH}\right)$, latiumite $\left(\mathrm{Ca}, \mathrm{K}_{2}\right)_{8} \mathrm{Al}{ }_{8}(\mathrm{Si}$, $\mathrm{Al})_{7} \mathrm{O}_{25}\left(\mathrm{SO}_{3}\right)$ and several other calcium and aluminum oxides.

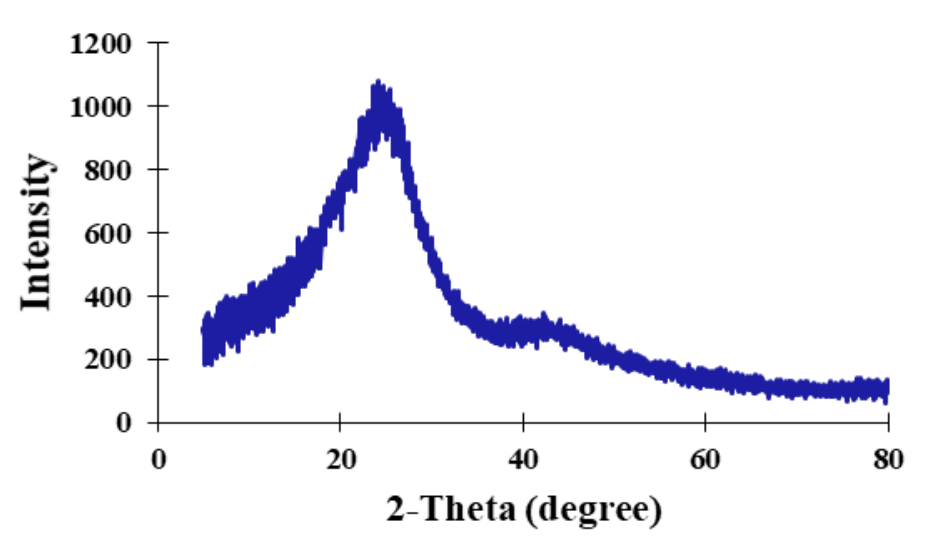

Fig. 2: Experimental diffraction pattern for activated carbon from coffee residue

The iodine number of the CARC is determined at $215.15 \mathrm{mg} \mathrm{I}_{2} / \mathrm{g}$; as an index of the surface area; It is relatively low; it is presumed that $\mathrm{H}_{3} \mathrm{PO}_{4}$ molecules occupied active carbon sites after impregnation. However, the coal studied does have acceptable adsorption capacity of $\mathrm{CN}^{-}$at a $\mathrm{pH}$ of 8 . In contrast to similar support Halet et al., (2015), found the iodine number at $460 \mathrm{mg} \mathrm{I}_{2} / \mathrm{g}$, the difference it could be, when using a higher activation temperature $\left(700{ }^{\circ} \mathrm{C}\right)$; according to Ghanizadeh and Asgari (2010), they determined it at $134.44 \mathrm{mg} \mathrm{I}_{2} / \mathrm{g}$ for bone carbon without any impregnation.

\section{c) Optimization of the adsorption process}

The DCC was applied with three factors adapted to three levels each and six central points; The effect of $\mathrm{pH}$, contact time, and dosage of CARC on the adsorption efficiency of $\mathrm{CN}^{-}$was studied. The adsorption 
percentages obtained from the experiments were entered in response to the matrix generated from the DOE (Minitab 18), according to Table 2. The data were analyzed using the response surface methodology (RSM) from the which derived the analysis of adjusted variance, where the factors $A, B, C$, and the $A A$ interaction, as well as the coefficients of Equation 5, were significant ( $p$-value $<\alpha=0.05$ ). Significant $F$ values indicated the suitability of the model, and the square of the regression coefficient (98.60\%) suggests that the model studied was consistent.

Table 2: Matrix for the central composite design, with the response variable based on process variables and coded

\begin{tabular}{cccccccc}
\hline \multirow{2}{*}{ Run order } & \multicolumn{5}{c}{ Process variable } & \multicolumn{3}{c}{ Coded variable } & \multirow{2}{*}{ Adsorption } & $\%$ \\
\cline { 2 - 6 } & $\mathrm{pH}$ & Time $(\mathrm{min})$ & Dosage $(\mathrm{g} / \mathrm{L})$ & $\mathrm{A}$ & $\mathrm{B}$ & $\mathrm{C}$ & -1 \\
\hline 1 & 9 & 90 & 20 & -1 & -1 & -1 & 38,77 \\
2 & 12 & 90 & 20 & 1 & -1 & -1 & 9,36 \\
3 & 9 & 180 & 20 & -1 & 1 & -1 & 43,74 \\
4 & 12 & 180 & 20 & 1 & 1 & -1 & 12,49 \\
5 & 9 & 90 & 40 & -1 & -1 & 1 & 48,74 \\
6 & 12 & 90 & 40 & 1 & -1 & 1 & 18,74 \\
7 & 9 & 180 & 40 & -1 & 1 & 1 & 53,12 \\
8 & 12 & 180 & 40 & 1 & 1 & 1 & 24,99 \\
9 & 7,977 & 135 & 30 & $-1,682$ & 0 & 0 & 54,68 \\
10 & 13,023 & 135 & 30 & 1,682 & 0 & 0 & 8,11 \\
11 & 10,5 & 59,32 & 30 & 0 & $-1,682$ & 0 & 31,22 \\
12 & 10,5 & 210,68 & 30 & 0 & 1,682 & 0 & 42,49 \\
13 & 10,5 & 135 & 13,182 & 0 & 0 & $-1,682$ & 24,99 \\
14 & 10,5 & 135 & 46,818 & 0 & 0 & 1,682 & 44,99 \\
15 & 10,5 & 135 & 30 & 0 & 0 & 0 & 34,60 \\
16 & 10,5 & 135 & 30 & 0 & 0 & 0 & 34,60 \\
17 & 10,5 & 135 & 30 & 0 & 0 & 0 & 33,90 \\
18 & 10,5 & 135 & 30 & 0 & 0 & 0 & 34,20 \\
19 & 10,5 & 135 & 30 & 0 & 0 & 0 & 34,60 \\
20 & 10,5 & 135 & 30 & 0 & 0 & 0 & 33,80 \\
\hline
\end{tabular}

$Y=34,25-14,43 A+2,76 B+5,48 C-1,68 A A$
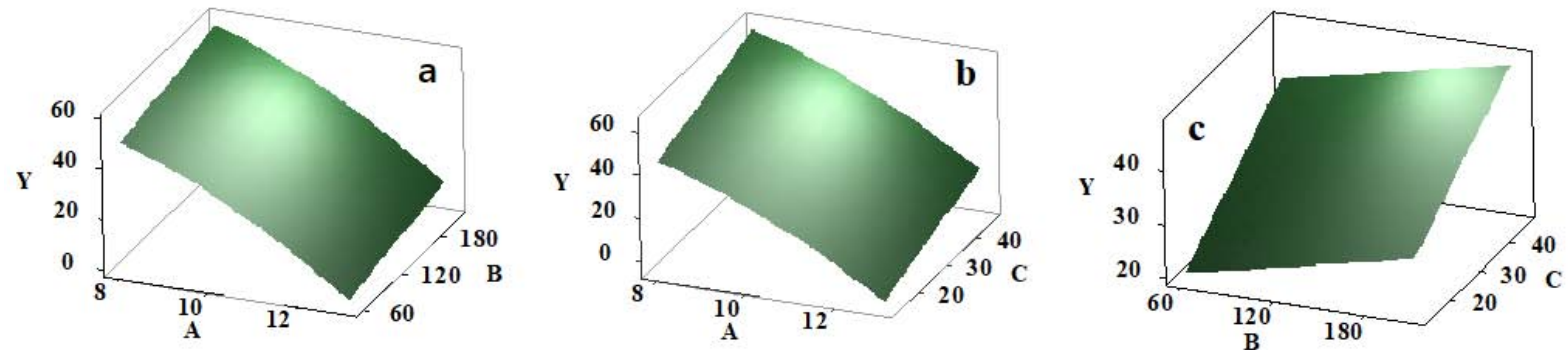

Fig. 3: Effects of the combination of factors on the percentage of adsorption of the $C^{-}(Y)$. a) $p H(A)$ vs contact time (B); b) $\mathrm{pH}(\mathrm{A})$ vs adsorbent dosage (C); c) contact time (B) vs adsorbent dosage (C).

Fig. 3 shows the 3D graphs of the response surface, which estimates the optimal values for the three factors under study. Thus, Figure 3 a shows the combined effect of $\mathrm{pH}$ and contact time; the adsorption increased to $55 \%$ when the $\mathrm{pH}$ dropped to 8 and the contact time increased to 220 minutes. Fig. 3b shows the combined effect of $\mathrm{pH}$ and the dosage of CARC; It is noted that when the $\mathrm{pH}$ dropped to 8 , and the dosage increased to $50 \mathrm{~g} / \mathrm{L}$, an adsorption percentage of approximately $55 \%$ is achieved. Fig. $3 c$ represented the combined effect of contact time and reagent dosage; the lowest adsorption percentage of $45 \%$ is obtained 
when the contact time and the dose of adsorbent increased to about 220 minutes and $50 \mathrm{~g} / \mathrm{L}$ respectively. Similar trends experiment Eletta et al. (2016) for the effects of the combination of its factors when using calcined eggshell for adsorption of cyanide.

According to the MSR; the maximum adjustment for the adsorption of the $\mathrm{CN}^{-}$of $67.65 \%$, was achieved with a $\mathrm{pH}$ of 7.98 , contact time of 210.68 minutes and dosage of $46.82 \mathrm{~g} / \mathrm{L}$ of the CARC; similar trend for a pH of 8, Gebresemati et al. (2017) in the improvement of cyanide adsorption by coffee husk. d) Study of Equilibrium and kinetic models

Table 3 shows the experimental values of the equilibrium isotherms studied: Freundlich model (Fig. 4a), Langmuir (Fig. 4b), and Temkin (Fig. 4c). Experimental data were obtained at room temperature $\left(30{ }^{\circ} \mathrm{C}\right), \mathrm{pH}$ of 8 , using $50 \mathrm{~mL}$ of solution with initial concentrations of $50,60,70,80,90,100,110,120,130$, $140 \mathrm{mg}$ of $\mathrm{CN} / \mathrm{L}$ and $1.5 \mathrm{~g}$ of adsorbent; stirred at 200 rpm for $140 \mathrm{~min}$.
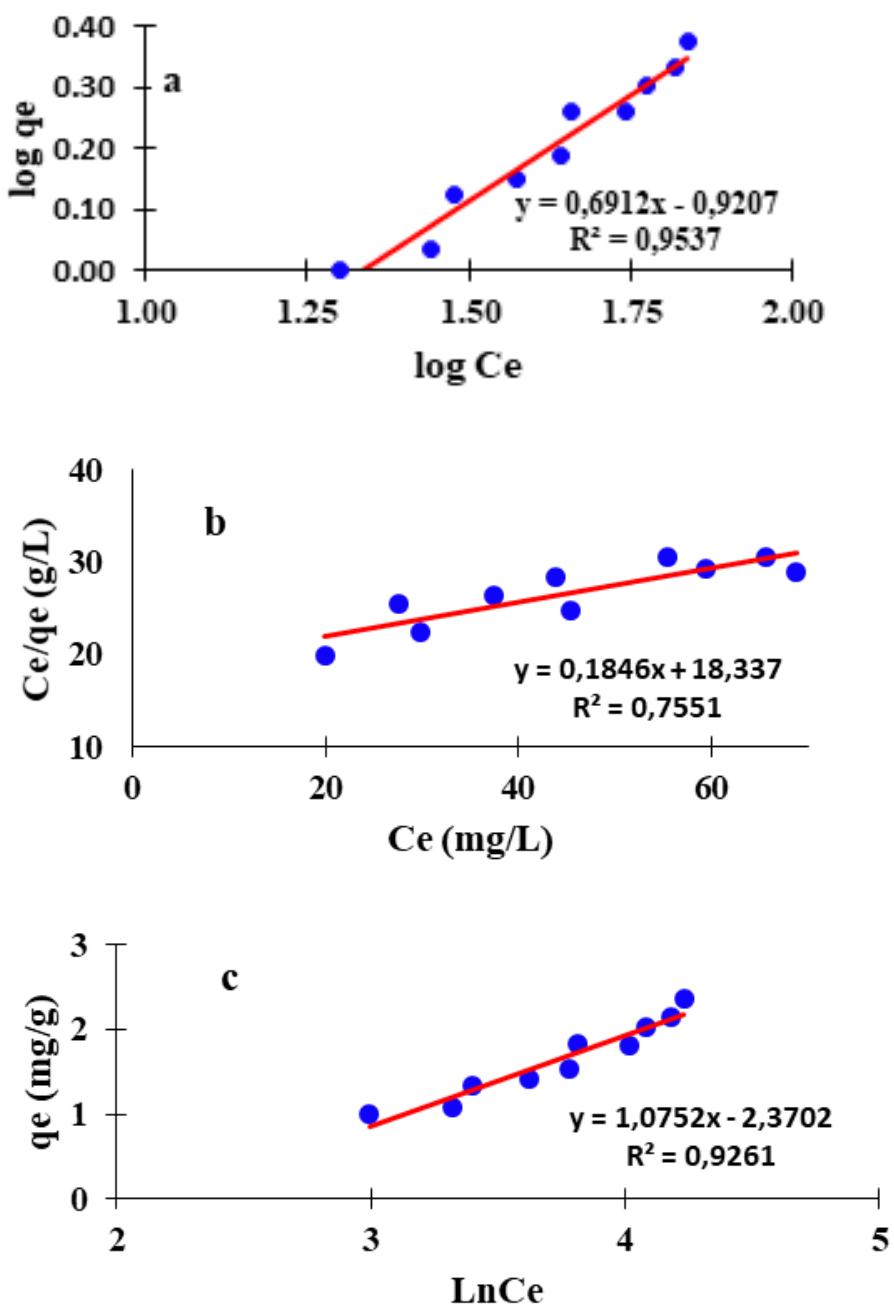

Fig. 4: Equilibrium models; a) Freundlich; b) Langmuir; c) Temkin. For the adsorption of $C N^{-}$onto activated carbon from coffee residue. Process conditions: $\mathrm{pH}$ : 8; room temperature: $30^{\circ} \mathrm{C}$; contact time: $140 \mathrm{~min}$; adsorbent dose: 30 $\mathrm{g} / \mathrm{L}$ and stirred at $200 \mathrm{rpm}$.

$\mathrm{R}^{2}$ values are in the following order: Freundlich (0.954)> Temkin (0.9261)> Langmuir (0.7551); suggests that the experimental values of the adsorption of $\mathrm{CN}^{-}$onto the CARC, fitted to the Freundlich model; its value of $n>1$, supports that the adsorption of the $\mathrm{CN}^{-}$is favorable and occurred in multilayers (physisorption); this according to Tsunatu et al. (2015) and Halet et al. (2015); both find that their data fitted to the Temkin and
Freundlich model, they report that the adsorption of $\mathrm{CN}^{-}$ did not occur in monolayer.

For the Langmuir isotherm, the maximum monolayer adsorption capacity is found to be $5.42 \mathrm{mg}$ $\mathrm{CN}^{-1} / \mathrm{g}$ CARC; its value $0<\mathrm{RL}(0.67)<1$ indicates that adsorption is favorable, according to Mondal et al. (2019) and Tsunatu et al. (2015) that they found, experimental values of $0<R L<1$ when removing 
cyanide with coke charcoal and shea seed husk respectively. However, the maximum adsorption capacity obtained in the equilibrium; It is relatively low, compared to the results obtained by Halet et al. (2015) and Stavropoulos et al. (2015); the first when using active carbon of similar support obtains $20.04 \mathrm{mg} \mathrm{CN} / \mathrm{g}$ at $20{ }^{\circ} \mathrm{C}$; it should, which applied higher temperature $\left(700{ }^{\circ} \mathrm{C}\right)$ and activation time $(2 \mathrm{~h})$; the second, by using active carbon D45/2 - Carbo Tech obtains maximum adsorption capacities of 28.3 and $21.25 \mathrm{mg} \mathrm{CN} / \mathrm{g}$, for $20{ }^{\circ} \mathrm{C}$ and $30{ }^{\circ} \mathrm{C}$ respectively and indicates that at low adsorption capacity there is a weak adsorption mechanism between cyanide and coal.

Table 3: Parameters and their values for the adsorption isotherms of the $\mathrm{CN}^{-}$onto the CARC

\begin{tabular}{lcc}
\hline Models & Parameters & Coefficients \\
\hline Freundlich & $\mathrm{R}^{2}$ & 0,954 \\
& $\mathrm{n}$ & 1,447 \\
& $1 / \mathrm{n}$ & 0,691 \\
Langmuir & $\mathrm{K}_{\mathrm{f}}(\mathrm{L} / \mathrm{mg})$ & 0,12 \\
& & \\
& $\mathrm{R}^{2}$ & 0,7551 \\
& $\mathrm{Q}_{\max }(\mathrm{mg} / \mathrm{g})$ & 5,42 \\
& $\mathrm{~b}(\mathrm{~L} / \mathrm{mg})$ & 0,01 \\
Temkin & $\mathrm{R}_{\mathrm{L}}$ & $0,67-0,42$ \\
& & \\
& $\mathrm{R}^{2}$ & 0,9261 \\
& $\mathrm{~B}(\mathrm{mg} / \mathrm{g})$ & 1,08 \\
& $\mathrm{~A}$ & 0,11 \\
\hline
\end{tabular}

The effect of contact time was studied (Fig. 5). The experimental results of equilibrium concentrations $(\mathrm{Ce})$ were carried out at room temperature $\left(30^{\circ} \mathrm{C}\right)$, with different times (20 - $200 \mathrm{~min}$ ) and initial concentrations of 80,100 , and $120 \mathrm{mg} / \mathrm{L}$ at $\mathrm{pH} 8$. Adsorption of cyanide onto CARC was very gradual, and the percentage of adsorbed cyanide increased for the initial low concentrations. That is, the adsorption efficiency depended of the initial cyanide concentration (Asgari et al., 2012), this is explained by the saturation of the active sites of the CARC as the concentration of $\mathrm{CN}^{-}$is higher in the solution (Eletta et al., 2016; Dwivedi et al., 2016).

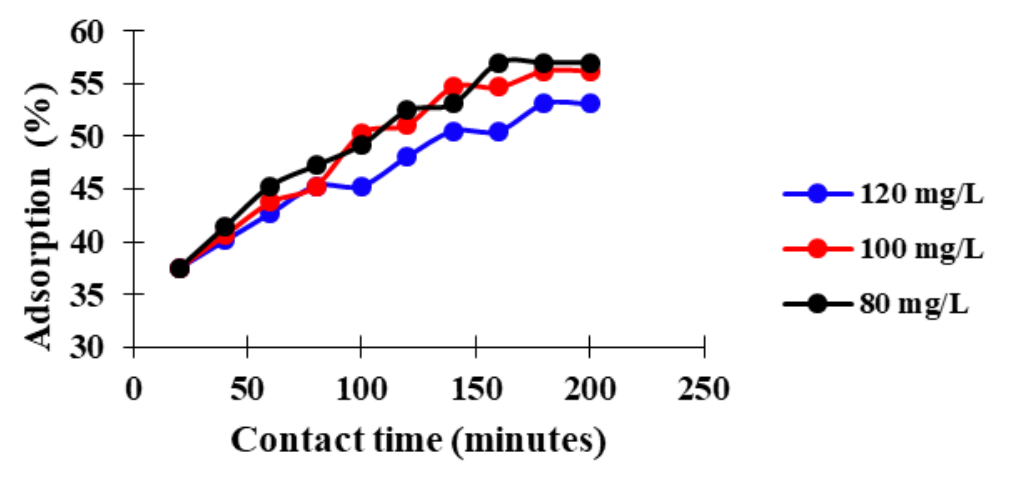

Fig. 5: Effect of contact time (20-200 min.) of the adsorption of the $\mathrm{CN}^{-}$onto the CARC. Process conditions: $\mathrm{pH}$ : 8; temperature: $30^{\circ} \mathrm{C}$; adsorbent dose: $30 \mathrm{~g} / \mathrm{L}$; initial cyanide concentration: 80, 100 and $120 \mathrm{mg} / \mathrm{L}$; rpm: 200

The adsorption kinetics of the $\mathrm{CN}^{-}$onto the CARC was studied according to the graphs for the kinetic models of the first pseudo (Fig. 6a) and secondorder (Fig. 6b), as well as the intraparticle diffusion model (Fig. 6c). The kinetic parameters with their results (Table 4) suggest that the adsorption kinetics of the $\mathrm{CN}^{-}$ onto the CARC, fitted to the pseudo second-order model. For the three initial concentrations under study (80, 100 , and $120 \mathrm{mg} / \mathrm{L}$ ), their $\mathrm{R}^{2}$ values of the three equations: $0.991,0.993,0.993$, are greater than the $R^{2}$ of the intraparticle diffusion model $(0.999,0.981,0.983)$ and that of pseudo-first order $(0.974,0.881,0.905)$. Eletta et al., (2016) and Tsunatu et al., (2015) in their studies found that the kinetic models of pseudo-second order explained the adsorption of cyanide onto the calcined egg shell and Shea Butter Seed Husk carbon, respectively.

Fig. 6c represents the correlation of the experimental data to three different initial concentrations and shows multilinearity; the first linear portion of 0 to $4.47 \mathrm{~min}^{0.5}$, is the steepest part, explains the immediate use of the active sites of the CARC by the $\mathrm{CN}^{-}$; It is 
generally attributed to the diffusion of the boundary layer (Dwivedi et al., 2016). The section from 4.47 to $6.32 \mathrm{~min}^{0.5}$ suggests that the internal diffusion process is a very gradual stage and illustrates the diffusion of macropores. The third portion represents the final stage of equilibrium or adsorption process itself, suggests the diffusion of micro and mesopores (Gupta et al., 2012); gradual for the adsorption of the $\mathrm{CN}^{-}$onto the CARC.
According to $R^{2}$ values $>0.98$, (for all three equations), the intraparticle diffusion model responds to the adsorption kinetics of the $\mathrm{CN}^{-}$onto the CARC and suggests the diffusion of $\mathrm{CN}^{-}$directly into the pores (Halet et al., 2015), so that intraparticle diffusion was not the limiting stage, during the adsorption process of the $\mathrm{CN}^{-}$onto CARC.
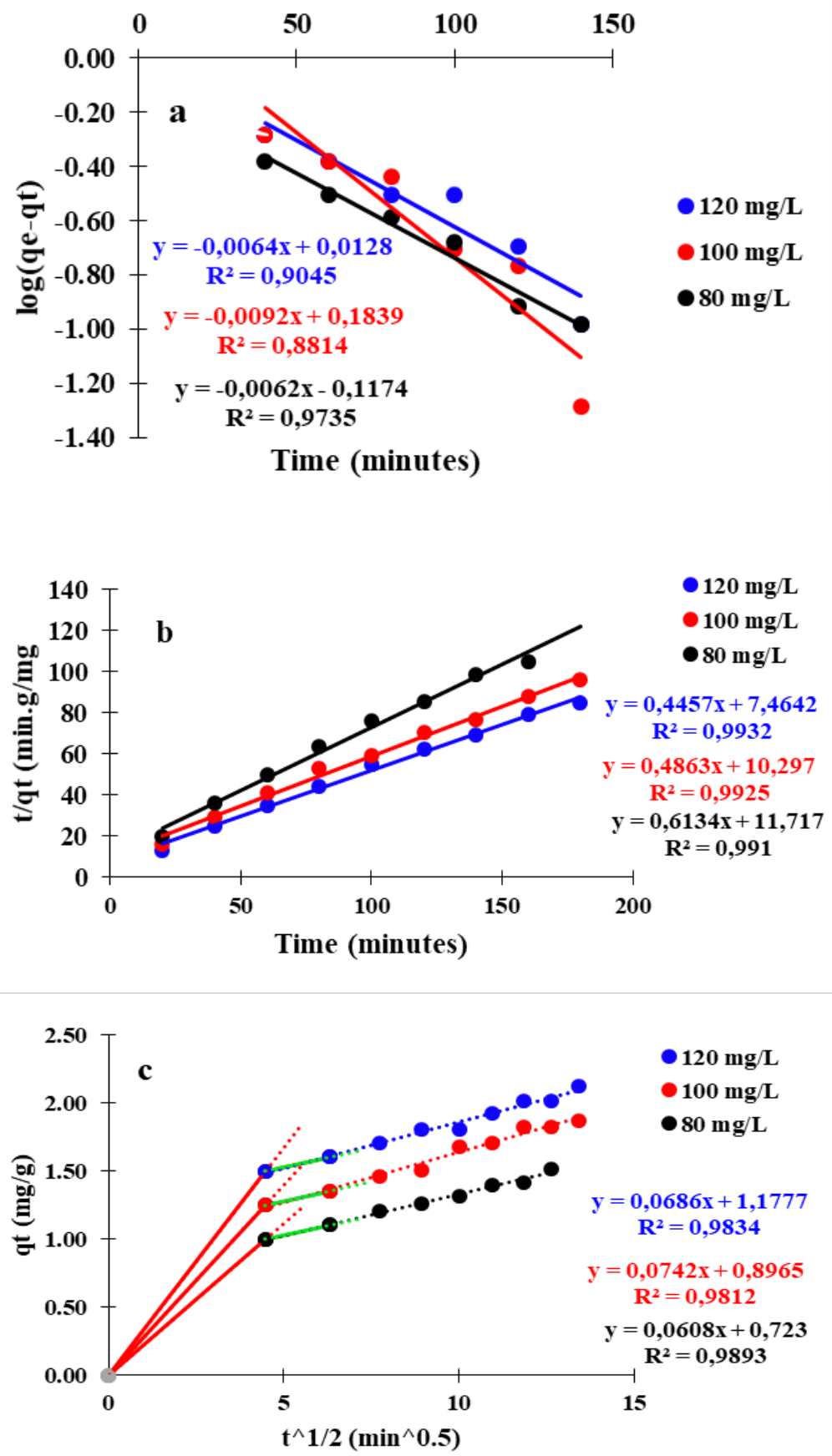

Fig. 6: Kinetic models: a) Pseudo-first order; b) Pseudo-second order; c) intraparticle diffusion, for the adsorption of $\mathrm{CN}^{-}$onto CARC. Process conditions: $\mathrm{pH}$ : 8; temperature: $30{ }^{\circ} \mathrm{C}$; adsorbent dose: $30 \mathrm{~g} / \mathrm{L}$; initial cyanide concentration: 80, 100 and $120 \mathrm{mg} / \mathrm{L}$; rpm: 200 
Tabla 4: Details of the parameters with their kinetic values for the adsorption of the $\mathrm{CN}^{-}$onto the CARC

\begin{tabular}{ccccccccccc}
\hline \multirow{2}{*}{$\begin{array}{c}\text { Co } \\
(\mathrm{mg} / \mathrm{L})\end{array}$} & \multicolumn{3}{c}{ Pseudo-first order model } & \multicolumn{3}{c}{ Pseudo-second order model } & \multicolumn{3}{c}{ Intra particle diffusion model } \\
\cline { 2 - 11 } & $\mathrm{K}_{1} \quad(\mathbf{1} / \mathrm{s})$ & $\mathrm{q}_{\mathrm{e}}(\mathrm{mg} / \mathrm{g})$ & $\mathrm{R}^{2}$ & $\begin{array}{c}\mathrm{K}_{2} \\
(\mathrm{~g} /(\mathrm{mg} \mathrm{s}))\end{array}$ & $\begin{array}{c}\mathrm{q}_{\mathrm{e}} \\
(\mathrm{mg} / \mathrm{g})\end{array}$ & $\mathrm{R}^{2}$ & $\mathrm{Kdi}\left(\mathrm{mg} / \mathrm{g} \mathrm{min} \mathbf{m}^{0.5}\right)$ & $\mathrm{C}(\mathrm{mg} / \mathrm{g})$ & $\mathrm{R}^{2}$ \\
\hline 80 & 0,014 & 0,76 & 0,97 & 0,032 & 1,63 & 0,99 & 0,061 & 0,72 & 0,99 \\
100 & 0,021 & 1,53 & 0,88 & 0,023 & 2,06 & 0,99 & 0,074 & 0,90 & 0,98 \\
120 & 0,015 & 1,03 & 0,91 & 0,027 & 2,24 & 0,99 & 0,069 & 1,18 & 0,98 \\
\hline
\end{tabular}

\section{Conclusions}

The optimization study was carried out and the equilibrium models of Freundlich, Langmuir and Temkin were evaluated, as well as the kinetic models of pseudost order, the pseudo-second order and intraparticle diffusion of the $\mathrm{CN}^{-}$adsorption process onto the CARC obtained from coffee residue. The FTIR, XRD analyzes confirmed the structural change of the precursor to activated carbon. The optimization study suggests that the adsorption process of $\mathrm{CN}^{-}$by CARC is sensitive to $\mathrm{pH}$; With its value of 8 , it reached $54.68 \%$ adsorption percentage and $67.65 \%$ for the predictive level. The factorial regression coefficient of $98.59 \%$ of its analysis of variance showed that the study was consistent. The larger $R^{2}$, for the equilibrium and kinetic studies, showed that the experimental data for cyanide adsorption onto the CARC, fitted to the Freundlich model (0.954) and pseudo-second order ( $>0.99)$ respectively and intraparticle diffusion ( $>0.98)$ responds to the adsorption kinetics of the $\mathrm{CN}^{-}$on the CARC. The values of $0<R L(0.67)<1$ and $n(1.45)>1$, for the Langmuir and Freundlich isotherms, respectively suggest that the adsorption of $\mathrm{CN}^{-}$on the CARC is favorable and according to the equlibrium model of Langmuir, maximum adsorption of $5.42 \mathrm{mg}$ of $\mathrm{CN}^{-} / \mathrm{g}$ of CARC is obtained. The feasibility of preparing activated charcoal using the spent coffee residue as support and could be used as adsorbent potential in the decontamination of wastewater containing low concentrations of $\mathrm{CN}^{-}$is demonstrated; however, new procedures for activating coffee residue, at different impregnation rates of $\mathrm{H}_{3} \mathrm{PO}_{4}$ and temperatures for chemical activation, could be studied to modify its surface and improve its adsorption capacity of $\mathrm{CN}^{-}$.

\section{ACKNOWLEDGMENTS}

To Dr. Raúl Siche Jara for his support in the FTIR analyzes in the Faculty of Agricultural Sciences and to Dr. Segundo Jáuregui Rosas for the XRD test of active carbon in the Academic Department of Physics; from the National University of Trujillo.

Disclaimer: None.

Conflict of Interest: None.

Source of Funding: None.

\section{REFERENCES}

1. Al Bahri M, Calvo L, Gilarranz M and Rodriguez J, 2012. Activated carbon from grape seeds upon chemical activation with phosphoric acid: Application to the adsorption of diuron from water. Chem. Eng. J. 203: 348-356.

2. Aranguri G and Reyes-lópez I, 2018. Cyanide degradation from mining effluent using two reagents: Sodium metabisulphite and the metabisulphite mixture with hydrogen peroxide. Tecciencia 13:1-9.

3. Asgari G, Ramavandi B, Mohammadi SM and Pour $A M, 2012$. The investigation of kinetic and isotherm of cyanide adsorption onto bone charcoal. En 4th International Conference on Chem., Biol. and Environ. Eng. 43: 119-124.

4. ASTM-D 4607, 2006. Determination of iodine number of activated carbon, pp. 1-5. In Estandard Test Method International. Estados Unidos.

5. Awasthi GP, Bhattarai DP, Maharjan B, Kyung-Suk $\mathrm{K}$, Park CH and Kim CS, 2019. Synthesis and characterizations of activated carbon from Wisteria sinensis seeds biomass for energy storage applications. J. of Industrial and Eng. Chem. 72: 262-272.

6. Azamat $J$ and Khataee A, 2017. Molecular dynamics simulations of removal of cyanide from aqueous solution using boron nitride nanotubes. Comput. Mater. Sci. 128: 8-14.

7. Ballesteros L, Teixeira $\mathrm{J}$ and Mussatto S, 2014. Chemical, functional, and structural properties of spent coffee grounds and coffee silverskin. Food and Bioprocess Technol. 7: 3493-3503.

8. Botz MM, Mudder TH and Akcil AU, 2016. Cyanide treatment: Physical, chem. and Biol. Processes, pp. 619-645. In M. D. Adam, Gold Ore Processing: Project Development and Operations. Elsevier, Amsterdam.

9. Dwivedi N, Balomajumder C and Mondal P, 2016. Comparative investigation on the removal of cyanide from aqueous solution using two different bioadsorbents. Water Resour. and Ind. 15: 28-40.

10. Dwivedi N, Balomajumder C and Mondal P, 2014. Studies of kinetic and equilibrium isotherm models 
for the sorption of cyanide ion on to almond shell. Res. J. of Chem. Sci. 4:20-24.

11. Eletta OA, Ajayi OA, Ogunleye $O O$ and Akpan IC, 2016. Adsorption of cyanide from aqueous solution using calcinated eggshells: Equilibrium and optimisation studies. J. of Environ. Chem. Eng. 4: 1367-1375.

12. Fombuena $M$ and Valentín A, 2010. Manual del carbón activo. Universidad de Sevilla.

13. Gebresemati M, Gabbiye N and Sahu O, 2017. Sorption of cyanide from aqueous medium by coffee husk: Response surface methodology. J. of Appl. Res. and Technol. 15: 27-35

14. Ghanizadeh $G$ and Asgari G, 2010. Adsorption kinetics and isotherm of methylene blue and its removal from aqueous solution using bone charcoal. Reac. Kinet. Mech. Cat. 102: 127-142.

15. Greenberg AE, Clesceri LS and Eaton AD, 1992. Standard Methods for the Examination of Water an Wastewater. 18 th edition. A. P. H. A. Washington.

16. Guang-zhen Z, Xian-lun D, Hou M, Sun K, Yan-ping, Z, Li P and Fang-min L, 2016. Comparative study on characterization and adsorption properties of activated carbons by phosphoric acid activation from corncob and its acid and alkaline hydrolysis residues. Fuel Process. Technol. 144: 255-261.

17. Gupta N, Balomajumder C and Agarwal V, 2012. Adsorption of cyanide ion on pressmud surface: A modeling approach. Chem. Eng. J. 191: 548-556.

18. Gupta N, Balomajumder C and Agarwa VK. 2013. Adsorptive treatment of cyanide-bearing wastewater: a prospect for sugar industry waste. Chem. Eng. Commun. 200: 993-1007.

19. Halet F, Yeddou AR, Chergui A, Chergui S, Boubekeur N and Ould-Dris A, 2015. Removal of cyanide in aqueous solution by adsorption on activated carbon prepared from lignocellulosic by products. J. of Dispersion Sci. and Tecnol.

20. Herrera EL, Feijoo CY, Alfaro R, Solís JL, Gómez MM, Keiski RL and Cruz GJ, 2018. Producción de biocarbón a partir de biomasa residual y su uso en la germinación y crecimiento en vivero de Capparis scabrida (Sapote). Scientia Agropecuaria 9: 569-577.

21. Imessaoudene D, Hanini S, Bouzidi $A$ and Ararem A, 2016. Kinetic and thermodynamic study of cobalt adsorption by spent coffee. Desalin. and Water Treat. 57: 6116-6123.

22. Liu C, Pujol D, Olivella M, De la Torre F, Fiol N, Poch J, Villaescusa I, 2015. The Role of Exhausted Coffee Compounds on Metal Ions Sorption. Water Air Soil Pollut. 226: 1- 10.

23. Luque-Almagro $\mathrm{V}$, Moreno-Vivián $\mathrm{C}$ and Roldán $\mathrm{M}$, 2016. Biodegradation of cyanide wastes from mining and jewellery industries. Curr. Opin. In Biotechnol. 38:9-13.
24. Ma X and Ouyang F, 2013. Adsorption properties of biomass-based activated carbon prepared with spent coffee grounds and pomelo skin by phosphoric acid activation. Appl. Surf. Sci. 268: 566-570.

25. Molina-Sabio M and Rodríguez-Reinoso F, 2004. Role of chemical activation in the development of carbon porosity. Colloids and Surf. A: Physicochem. Eng. Aspects 241: 15-25.

26. Mondal M, Mukherjee R, Sinha A, Sarkar S and De $S$, 2019. Removal of cyanide from steel plant effluent using coke breeze, a waste product of steel industry. J. of Water Process Eng. 28: 135-143.

27. Mussatto SI, Machado EM, Martins S and Teixeira JA, 2011. Production, composition, and application of coffee and its industrial residues. Food Bioprocess Technol. 4: 661-672.

28. NMX-F-296-SCFI. 2011. Norma mexicana NMX-F296-SCFI-2011 Industria azucarera y alcoholera determinación del número de yodo en muestras de carbones activados empleados en la refinación de azúcar, pp. 1-11. Mexico.

29. Naeem S, Zafar U and Amann T, 2011. Adsorption studies of cyanide $\mathrm{CN}^{-}$on rice husk ash (RHA). Bangladesh J. of Sci. and ind. Res. 46: 101-104.

30. Oliveira LS and Franca AS, 2015. An overview of the potential uses for coffee husks, pp. 283-291. In V. Preedy (Ed.), Coffee in Health and Disease Prevention. Elsevier. Londres.

31. Qing-Song L, Zheng T, Wang P and Guo L, 2010. Preparation and characterization of activated carbon from bamboo by microwave-induced phosphoric acid activation. Ind. Crops and Prod. 31: 233-238.

32. Rattanapan S, Srikram J and Kongsune P, 2017. Adsorption of methyl orange on coffee grounds activated carbon. Energy Procedia 138: 949-954.

33. Rawal S, Joshi B and Kumar Y, 2018. Synthesis and characterization of activated carbon from the biomass of Saccharum bengalense for electrochemical supercapacitors. J. of Energy Storage 20: 418-426.

34. Reffas A, Bernardet V, David B, Reinert L, Lehocine B, Dubois M, Btisse N, Duclaux L, 2010. Carbons prepared from coffee grounds by $\mathrm{H}_{3} \mathrm{PO}_{4}$ activation: Characterization and adsorption of methylene blue and Nylosan Red N-2RBL. J. of Hazard. Mtls 175: 779-788.

35. Shamsuddin M, Yusoff N and Sulaiman M, 2016. Synthesis and characterization of activated carbon produced from kenaf core fiber using $\mathrm{H}_{3} \mathrm{PO}_{4}$ activation. Procedia Chem. 19: 558-565.

36. Singh N and Balomajumder C, 2016. Simultaneous removal of phenol and cyanide from aqueous solution by adsorption onto surface modified activated carbon prepared from coconut shell. J. of Water Process Eng. 9: 233-245. 
37. Stavropoulos GG, Papadopoulou M and Papadimitriou K, 2015. A kinetic and thermodynamic study of cyanide adsorption in activated carbon. Desalin. and Water Treat. 57: 1-5.

38. Tsunatu DY, Taura UH and Jirah EU, 2015. Kinetic studies of bio-sorption of cyanide ions from aqueous solution using carbon black developed from shea butter seed husk as an adsorbent. Am. Chem. Sci. J. 8: 1-12.

39. Vogel, A. I. 1989. Text book of quantitative chemical analysis, pp. 358. 5ta Edicion. Longman Group UK Limite, Londres.

40. Weber WJ and Morris JC, 1963. Kinetics of adsorption carbon from solutions. J. Sanitary Eng. Division. 89: 31-60. 